\title{
Growth of the seagrass Heterozostera tasmanica limited by nitrogen in Port Phillip Bay, Australia
}

\author{
Douglas A. Bulthuis*, Donald M. Axelrad**, Michael J. Mickelson*** \\ Marine Science Laboratories, Department of Conservation and Environment, Queenscliff, Victoria 3225, Australia
}

\begin{abstract}
Growth of the seagrass Heterozostera tasmanica (Martens ex Aschers.) den Hartog in the sandy sediments of Port Phillip Bay, southeastern Australia, is shown to be limited by nitrogen (but not phosphorus) in the sediment interstitial water Sediments beneath $H$. tassmanica at 5 sites in the bay were enriched in spring (September) with nitrogen $\left(1000 \mathrm{~g} \mathrm{~m}^{-2}\right)$ and phosphorus $\left(20 \mathrm{~g} \mathrm{P} \mathrm{m}^{-2}\right)$; responses were measured 5 mo later in late summer (February). At 1 site, Rye, nitrogen and phosphorus were added both separately and together in a $2 \times 2$ factorial design; at the other 4 sites nitrogen and phosphorus were added together. At the Rye site, nitrogen enrichment resulted in an increased concentration of total nitrogen in the roots/rhizomes and leaves of $H$. tasmanica and in a significant increase in dry weight of leaves $(50 \%)$, density of leaf clusters $(40 \%)$ and canopy height $(20 \%)$. Phosphorus enrichment resulted in an increased concentration of phosphorus in the leaves of $H$. tasmanica but no change in leaf dry weight, density of leaf clusters or canopy height. Neither nitrogen nor phosphorus enrichment caused an increase in dry weight of epiphytes on seagrass leaves, in dry weight of non-epiphytic macroalgae or in the concentration of chlorophyll in seagrass leaves. At 3 of the 4 other sites, nitrogen plus phosphorus enrichment resulted in an increase in growth of $H$. tasmanica. It is suggested that during spring and summer nitrogen limits the growth of $H$ tasmanica throughout most of Port Phillip Bay
\end{abstract}

\section{INTRODUCTION}

The effects of nutrient enrichment on growth of seagrasses and the relative importance of nitrogen vs phosphorus on seagrass growth have been the subject of several recent studies. Seagrasses absorb nutrients from the water through their leaves or from the sediments through their roots (McRoy \& Barsdate 1970, Iizumi \& Hattori 1982, Thursby \& Harlin 1982, Short 1983a, b, Short \& McRoy 1984, Brix \& Lyngby 1985 , Borum et al. 1989). Because seagrasses usually grow in substrata whose concentrations of nitrogen and phosphorus are higher than those of the overlying water, nutrient concentrations in the sediment are considered more important in determining whether growth of sea-

Present addresses:

- Padilla Bay National Estuarine Research Reserve, 1043 Bayview-Edison Road, Mount Vernon, Washington 98273, USA

- The Nature Conservancy, Florida Keys Initiative, PO Box 4958, Key West, Florida 33041, USA

-. Massachusetts Water Resources Authority, Charlestown Navy Yard, 100 First Ave., Boston, Massachusetts 02129, USA grasses is nutrient limited (Brix \& Lyngby 1985, Boon 1986, Short 1987).

Enrichment of the sediment and root environment of Zostera marina and Ruppia maritima by nitrogen and phosphorus has increased growth of these seagrasses thus demonstrating nutrient limitation in the field (Orth 1977, Orth \& Moore 1982, Roberts et al. 1984, Pulich 1985). In a review of the effects of the nutrient concentration of the substratum on the growth of seagrasses, Short (1987) suggested that nitrogen will generally be limiting in terrigenous sediments whereas phosphorus would be limiting in carbonate sediments of the tropics. Recent studies in which such carbonate sediments were enriched with phosphorus have provided evidence for phosphorus being the limiting nutrient for seagrasses in these environments (Powell et al. 1989, Short et al. 1990, Perez et al. 1991). But Zimmerman et al. (1987) have disputed the suggestion that nitrogen limits the growth of seagrass in nature on the basis of their model of seagrass growth. Field evidence that nitrogen may not always limit growth of $Z$. marina has been provided by Dennison et al. (1987). Similar evidence was obtained by Bulthuis \& Woelkerling (1981) who found no increase in the dry weight of leaves or 
the plant density of Heterozostera tasmanica in sediments enriched with ammonium, phosphate or with both in Western Port, Australia.

The objectives of the present study were to determine the effects of in situ nitrogen and phosphorus enrichment of the sediments in Port Phillip Bay on growth of the seagrass Heterozostera tasmanica. In Port Phillip Bay H. tasmanica grows in a sandy substratum markedly different from the muddy substratum in Western Port (southeastern Australia) where Bulthuis \& Woelkerling (1981) carried out their study. In Port Phillip Bay, with a large urban center in its watershed, concentrations of nutrients are high in the water column but low in the substratum compared to Western Port, which has a forested and agricultural watershed. In this paper we present evidence that nitrogen availability in the sediments limits growth of H. tasmanica in Port Phillip Bay.

\section{STUDY SITE}

Port Phillip Bay is a $2000 \mathrm{~km}^{2}$ marine embayment with a largely urbanized watershed (Melbourne, population 3 million). The bay receives about one-half the flow of Melbourne's treated sewage. Phosphate concentrations in the water are enriched about 20 times over those in Bass Strait (1.5 to $5.2 \mu \mathrm{M} \mathrm{PO}_{4}{ }^{-3}$ ) and, as may be expected in a sewage-enriched nitrogenlimited bay, the inorganic nitrogen concentrations range from very low to very high $(0.2$ to $15.8 \mu \mathrm{M}$ DIN; Axelrad et al. 1981, Bulthuis \& Woelkerling 1983a). The bay contains about $100 \mathrm{~km}^{2}$ of seagrass beds, mainly Heterozostera tasmanica (Bulthuis 1982). The sediments in Port Phillip Bay are sand and silty sand in the areas with seagrasses (Beasley 1966)

\section{METHODS}

For our experiments, we selected 5 experimental sites typical of the range of nutrient characteristics and water depths in which Heterozostera tasmanica grows

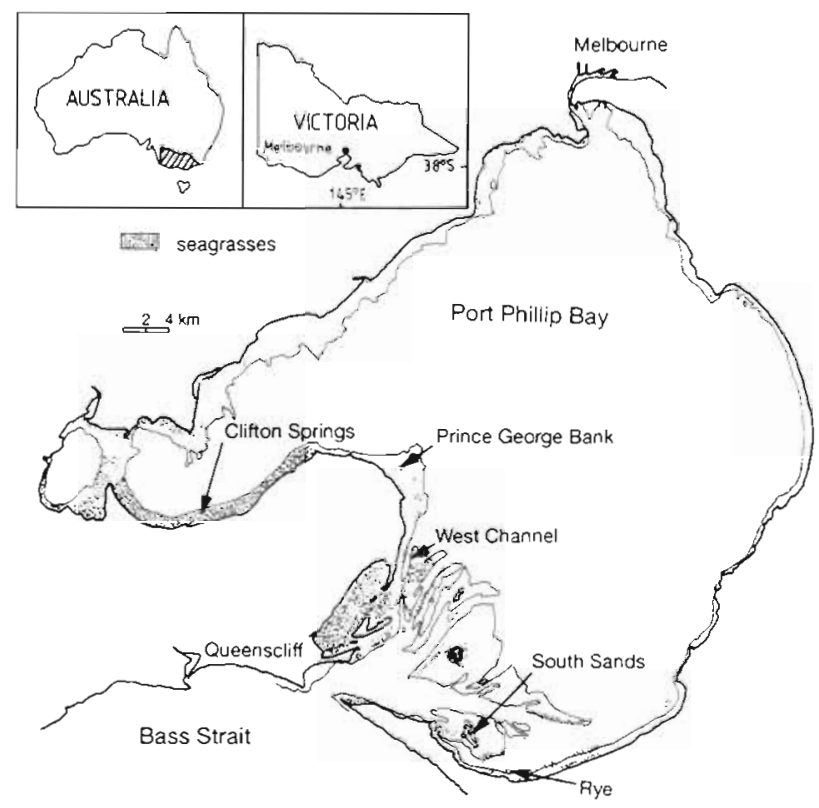

Fig. 1. Distribution of seagrasses (stippled area; Bulthuis 1982) and location of experimental sites in Port Phillip Bay. Australia. Thin line indicates $5 \mathrm{~m}$ depth contour

in Port Phillip Bay (Fig. 1, Table 1). Four sites (Rye, South Sands, West Channel and Clifton Springs) were located in stands of $H$. tasmanica that extended at least $200 \mathrm{~m}$ in all directions from the site. At Prince George Bank the cover of $H$. tasmanica was sparse and consisted of patches about $3 \times 5 \mathrm{~m}$. At the West Channel site, interaction between the seagrasses and fauna was apparent: bivalves, particularly Electroma sp., weighted many of the leaves down to the sediment, and a burrowing crustacean, probably a Callianassa species, buried some $H$. tasmanica leaves beneath mounds of sand as has been observed by Suchanek (1983).

At all sites except Rye, 3 plots were enriched with nitrogen and phosphorus and 3 plots were designated control plots. At the Rye site, a $2 \times 2$ factorial experimental design (modified to include 2 types of controls) was used to test the effect of (1) enrichment with phosphorus alone, (2) enrichment with nitrogen alone,

Table 1. Water depth and nutrient concentrations at 5 experimental sites in Port Phillip Bay in September 1982 (n $=2$ to 4 )

\begin{tabular}{|c|c|c|c|c|c|}
\hline \multirow[t]{3}{*}{ Site } & \multirow{3}{*}{$\begin{array}{c}\text { Depth } \\
\text { (m below } \\
\text { mean water) }\end{array}$} & \multicolumn{4}{|c|}{ Concentrations of nutrients in: } \\
\hline & & \multicolumn{2}{|c|}{ Water column (mid-depth) } & \multicolumn{2}{|c|}{ Interstitial water of sediment } \\
\hline & & $\begin{array}{l}\text { Orthophosphate } \\
\left(\mu \mathrm{MPO}_{4}^{-3}\right)\end{array}$ & $\begin{array}{c}\text { Inorganic nitrogen } \\
(\mu \mathrm{M} D \mathrm{DIN})\end{array}$ & $\begin{array}{c}\text { Orthophosphate } \\
\left(\mu \mathrm{M} \mathrm{PO}_{4}^{-3}\right)\end{array}$ & $\begin{array}{c}\text { Inorganic nitrogen } \\
(\mu \mathrm{M} \text { DIN })\end{array}$ \\
\hline Rye & 7 & 1.0 & 0.7 & 6.3 & 19 \\
\hline South Sands & 6 & 0.9 & 0.2 & 5.6 & 19 \\
\hline West Channel & 5 & 1.0 & 0.9 & 8.0 & 14 \\
\hline Prince George Bank & 3 & 1.5 & 0.1 & 5.9 & 19 \\
\hline Clifton Springs & 4 & 1.1 & 0.3 & 5.8 & 11 \\
\hline
\end{tabular}


(3) enrichment with a mixture of nitrogen and phosphorus.

At each site the sediments of 3 plots $(1.0 \times 1.0 \mathrm{~m})$ were enriched in September (early spring) with ' 6 month nitrogen Osmocote' (Osmocote ${ }^{\mathrm{TM}}$, Sierra Chemical Co.) or '8-9 month phosphorus Osmocote' slow release fertilizers. The Osmocote was wrapped in gauze cloth packets and at each plot 25 such packets were set out on an evenly divided grid marking system and buried at a depth of $0.1 \mathrm{~m}$ below the sediment surface. Rates of application of nitrogen and phosphorus were high $\left(100 \mathrm{~g} \mathrm{~N} \mathrm{~m}^{-2}\right.$ and $20 \mathrm{~g} \mathrm{P} \mathrm{m}^{-2}$, based on manufacturer's nominal values, which were confirmed by limited testing in our labsl so that computed uptake rates would be saturated throughout the experiment (Bulthuis \& Woelkerling 1981); the high rates ensured that neither nitrogen nor phosphorus would be growth limiting in plots enriched with these nutrients.

At all sites except Rye each plot was paired with a plot disturbed as if packets of Osmocote had been buried there (control group). At Rye 2 types of controls were used. In one type of control the sediments were disturbed in a similar manner to that of plots where packets had been buried (disturbed control). In the second type of control the sediments were left undisturbed (undisturbed control).

The concentrations of ammonium, nitrate and reactive phosphate in the sediment interstitial water were determined monthly during the experiment and the responses of Heterozostera tasmanica were measured in February 1983 (late summer) when the plants' growth, standing crop and density are expected to be at an annual maximum (Bulthuis \& Woelkerling 1983a).

Sediment interstitial water was sampled (4 samples per plot) by withdrawing water from $0.1 \mathrm{~m}$ depth in the sediment with a $100 \mathrm{ml}$ syringe. The sample was filtered immediately through a Whatman GF/C filter on board ship, and the filtrate was acidified to prevent formation of iron hydroxide/ferric phosphate (Loder et al. 1978). Each acidified filtrate was immediately frozen on dry ice. Reactive phosphorus, ammonium and nitrate plus nitrite were determined in an autoanalyser by the methods of Strickland \& Parsons (1972). The effect of the sample's exposure to air during sampling and filtering (about $30 \mathrm{~min}$ ) was examined on several occasions by conducting these procedures in a nitrogen atmosphere. Nutrient concentrations in samples collected and filtered under nitrogen were not significantly different from those of samples exposed briefly to the air.

Density of leaf clusters (i.e. branches terminated by a cluster of leaves) of Heterozostera tasmanica was counted in situ in 4 randomly (from a table of random numbers) allocated replicate quadrats $(0.20 \times 0.20 \mathrm{~m})$ in each plot. Dry weight of $H$. tasmanica was determined in 3 randomly allocated replicates in each plot; leaves, stems, roots and macroalgae at the Rye site by the methods described by Bulthuis \& Woelkerling (1983a), and leaf dry weight at all other sites by the methods described by Bulthuis \& Woelkerling (1981).

The concentrations of nitrogen and phosphorus in the leaves and roots/rhizomes were determined on a subsample of 20 plants from each sample used to measure dry weight at the Rye site by the methods described in Bulthuis \& Wolkerling (1981).

In each plot, the height of the seagrass canopy was measured at 5 randomly allocated positions by measuring the height from the sediment surface to the top of the tallest leaf within a $10 \mathrm{~cm}$ radius of each position. At the Rye site the concentration of chlorophyll (chl) $a$ and $b$ was determined in non-epiphytised leaves in the second plastochrome interval since their emergence (older leaves had numerous epiphytes) from 4 randomly selected plants per plot. Leaves were frozen immediately after sampling and analyzed within $2 \mathrm{wk}$ (separate tests indicated that concentrations of chl $a$ or $b$ in samples stored in this way were not significantly different from those of fresh samples). Leaves were crushed in a tissue grinder and extracted in $90 \%$ acetone for 16 to $20 \mathrm{~h}$. The optical densities of the extracts were measured at 647 and $664 \mathrm{~nm}$ and converted to $u \mathrm{M}$ of chl $a$ and $b$ using the equations of Jeffrey \& Humphrey (1975).

The dry weight of epiphytes on the leaves of Heterozostera tasmanica in the sixth plastochrome interval since their emergence was determined for 4 plants selected at random from each plot at the Rye site by the methods described in Bulthuis \& Woelkerling (1983b)

Results from the treated plots and control plots at Rye were compared by 2-way analysis of variance (A: nitrogen enrichment, B: phosphorus enrichment). Results from treatment plots and control plots at the other sites were compared by 1 -way analysis of variance.

\section{RESULTS}

\section{Controls}

There were no significant differences between disturbed and undisturbed controls in concentration of nutrients in sediment interstitial water as measured by ammonium, nitrate plus nitrite, or phosphate nor in plant response as measured by leaf cluster density, leaf dry weight or canopy height. Therefore, data for disturbed controls and undisturbed controls were pooled and used as 'control' data for all parameters measured at the Rye site. 

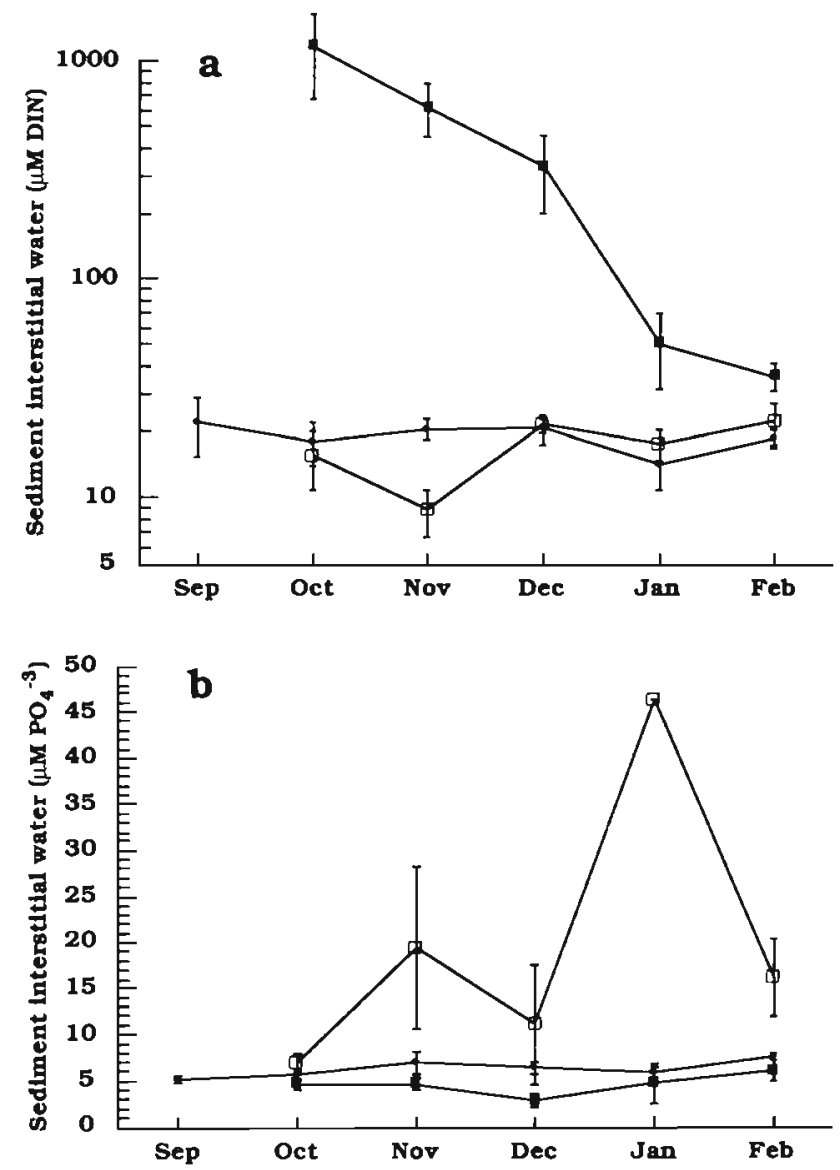

Fig. 2. Nutrients in interstitial water of sediments at the Rye site. Mean $+\mathrm{SE}_{1} \mathrm{n}=3$ or 6 plots with 4 measurements per plot. (a) Concentration of DIN in control ( $\bullet$ plots and in experimental plots enriched with nitrogen alone or with nitrogen plus phosphorus ( $)$ or enriched with phosphorus (). (b) Concentration of phosphate in control ( $\bullet$ plots and in experimental plots enriched with nitrogen alone ( $\bullet$ ) or phosphorus alone or with phosphorus plus nitrogen $(\Leftrightarrow)$. SE for Jan open square is greater than the mean and is not plotted

\section{Sediment chemistry}

At the Rye site the concentration of DIN (ammonium plus nitrate plus nitritej in sediment interstitial water increased almost 100 -fold during the first month after nitrogen enrichment and slowly declined during subsequent months (Fig. 2a). After enrichment with phosphorus the concentration of phosphate also increased (Fig. 2b), but not as rapidly as did DIN in nitrogenenriched plots. Thus, the method of treatment used at Rye increased the availability of nitrogen and phosphorus to Heterozostera tasmanica.

At 3 of the other 4 sites the concentrations of DIN in sediment interstitial water of the treated plots were 4 to 10 times higher than those in control plots in February 1983 at the end of the experimental period (Table 2). In contrast, at the Prince George Bank site concentrations of DIN in treated plots were not significantly different from those of control plots (Table 2 ).

\section{Effects on Heterozostera tasmanica}

At Rye, in February (summer), 5 mo after nutrient enrichment, density of leaf clusters was $40 \%$ higher, leaf dry weight was 36 to $62 \%$ higher and canopy height was $20 \%$ higher for Heterozostera tasmanica as a result of nitrogen addition (Table 3 ). Enrichment with phosphorus alone had no significant effect on growth of $H$. tasmanica. No significant interactive effects resulted from the addition of both nitrogen and phosphorus (Table 3). Chlorophyll concentration in the leaves of $H$. tasmanica and dry weight of epiphytes on the leaves did not change significantly ( $p>0.05$ ) after enrichment by either nitrogen or phosphorus, alone or in combination (Table 3).

Table 2. Heterozostera tasmanica. Density of leaf clusters, dry weight of leaves and canopy height and concentration of DIN and reactive phosphate in the interstitial water of the sediment at 4 sites in Port Phillip Bay in February 1983 after enrichment of the sediments with $\varepsilon$ mixture of nitrogen and phosphorus in September 1982 . Mean $\pm \mathrm{SE}, \mathrm{n}=3$ plots. ${ }^{\cdot} \mathrm{p}<0.05_{i}{ }^{\cdots} \mathrm{p}<0.01\left(1\right.$-way $^{-}$ ANOVA)

\begin{tabular}{|c|c|c|c|c|c|c|}
\hline Site & Treatment & $\begin{array}{l}\text { Density of } \\
\text { leaf clusters } \\
\text { (no. } \mathrm{m}^{-2} \text { ) }\end{array}$ & $\begin{array}{c}\text { Dry weight } \\
\text { of leaves } \\
\left(\mathrm{g} \mathrm{m}^{-2}\right)\end{array}$ & $\begin{array}{c}\text { Canopy } \\
\text { height } \\
\text { (cm) }\end{array}$ & $\begin{array}{l}\text { Interstitial } \\
\text { nitrogen } \\
(u M \text { DIN) }\end{array}$ & $\begin{array}{l}\text { Interstitial } \\
\text { phosphate } \\
\left(\mu \mathrm{M} \mathrm{PO}_{4}^{-3}\right)\end{array}$ \\
\hline South Sands & $\begin{array}{l}\text { Control } \\
+N+P\end{array}$ & $\begin{array}{c}1000 \pm 90 \\
2060^{\cdots} \pm 154\end{array}$ & $\begin{array}{l}153 \pm 15 \\
220 \pm 58\end{array}$ & $\begin{array}{r}35 \pm 1 \\
41^{\cdot} \pm 2\end{array}$ & $\begin{array}{l}20.1 \pm 2.8 \\
80.5 \pm 36.0\end{array}$ & $\begin{array}{l}6.8 \pm 0.7 \\
6.5 \pm 0.9\end{array}$ \\
\hline West Channel & $\begin{array}{l}\text { Control } \\
+N+P\end{array}$ & $\begin{array}{l}695 \pm 114 \\
910 \pm 90\end{array}$ & $\begin{array}{l}60 \pm 13 \\
79 \pm 17\end{array}$ & $\begin{array}{l}30 \pm 4 \\
40 \pm 4\end{array}$ & $\begin{array}{c}16.6 \pm 3.1 \\
177 \pm 92\end{array}$ & $\begin{array}{l}7.3 \pm 1.2 \\
7.4 \pm 0.6\end{array}$ \\
\hline Prince George Bank & $\begin{array}{l}\text { Control } \\
+N+P\end{array}$ & $\begin{array}{l}640 \pm 128 \\
695 \pm 141\end{array}$ & $\begin{array}{l}26 \pm 4 \\
34 \pm 9\end{array}$ & $\begin{array}{l}18 \pm 1 \\
20 \pm 1\end{array}$ & $\begin{array}{l}14.9 \pm 2.7 \\
15.0 \pm 1.3\end{array}$ & $\begin{array}{l}7.2 \pm 0.9 \\
6.0 \pm 1.4\end{array}$ \\
\hline Clifton Springs & $\begin{array}{l}\text { Control } \\
+N+P\end{array}$ & $\begin{array}{l}1590 \pm 148 \\
2270 \pm 329\end{array}$ & $\begin{array}{r}87 \pm 7 \\
143 \cdots \pm 3\end{array}$ & $\begin{array}{r}32 \pm 2 \\
46^{\cdots} \pm 1\end{array}$ & $\begin{array}{l}10.6 \pm 1.4^{a} \\
46.2 \pm 25.9\end{array}$ & $\begin{array}{l}5.8 \pm 0.4 \\
7.8 \pm 1.9\end{array}$ \\
\hline $\mathrm{NH}_{\phi}{ }^{+}$only & & & & & & \\
\hline
\end{tabular}


Table 3. Heterozostera tasmanica. Density of leaf clusters, leaf dry weight, canopy height, chlorophyll concentration in leaves and dry weight of epiphytes on leaves at the beginning (September 1982) and end (February 1983) of experimental enrichment of the sediments with nitrogen alone or phosphorus alone or a mixture of both nitrogen and phosphorus at the Rye site. Mean $\pm S E, n=3$ plots. The significance of the $F$ ratios are indicated: ${ }^{\circ} p<0.05 ; \cdots p<0.01$; ns: not significant, $p>0.05$

\begin{tabular}{|c|c|c|c|c|c|}
\hline & $\begin{array}{l}\text { Density of } \\
\text { leaf clusters } \\
\left(\text { no. } \mathrm{m}^{-2}\right)\end{array}$ & $\begin{array}{c}\text { Dry weight } \\
\text { of leaves } \\
\left(\mathrm{g} \mathrm{m}^{-2}\right)\end{array}$ & $\begin{array}{c}\text { Canopy } \\
\text { height } \\
\text { (cm) }\end{array}$ & $\begin{array}{c}\text { Leaf } \\
\text { chlorophyll } \\
\left(\mu \mathrm{g} \mathrm{cm}^{-2}\right)\end{array}$ & $\begin{array}{l}\text { Dry weight } \\
\text { of epihytes } \\
\left(\mathrm{mg} \mathrm{cm}^{-2}\right)\end{array}$ \\
\hline Initial (Sep 82) & $750 \pm 66$ & $28.7 \pm 3.3$ & & & \\
\hline \multicolumn{6}{|l|}{ Final } \\
\hline Control (Feb 83) & $740 \pm 22$ & $47.9 \pm 1.7$ & $30.1 \pm 0.6$ & $23.7 \pm 0.8$ & $3.75 \pm 0.36$ \\
\hline$+\mathrm{N}($ Feb 83) & $1030 \pm 139$ & $65.2 \pm 11.0$ & $35.5 \pm 2.1$ & $24.9 \pm 1.0$ & $3.58 \pm 0.10$ \\
\hline$+\mathrm{P}($ Feb 83) & $770 \pm 165$ & $45.2 \pm 4.4$ & $29.4 \pm 1.7$ & $23.2 \pm 1.1$ & $1.98 \pm 0.14$ \\
\hline$+N+P(F e b 83)$ & $1100 \pm 119$ & $77.5 \pm 8.0$ & $37.3 \pm 2.2$ & $25.1 \pm 1.5$ & $2.60 \pm 0.95$ \\
\hline \multicolumn{6}{|l|}{ ANOVA } \\
\hline$N$ enrichment & $\cdot$ & $\cdots$ & $\cdots$ & ns & ns \\
\hline P enrichment & ns & ns & ns & ns & ns \\
\hline $\mathrm{N} \times \mathrm{P}$ interaction & ns & ns & ns & ns & ns \\
\hline
\end{tabular}

Concentration of total nitrogen in Heterozostera tasmanica at the Rye site increased significantly from 1.7 to $2.1 \%$ in the leaves and from 0.5 to $0.9 \%$ in the roots/rhizomes after enrichment with nitrogen (Table 4). Similarly, the concentration of total phosphorus in the leaves increased after enrichment with phosphorus. Total phosphorus concentrations in the roots/rhizomes were not affected by the phosphorus addition (Table 4). After enrichment of the sediments with nitrogen the total phosphorus concentration in the roots/rhizomes was significantly lower $(p<0.05)$ and the total phosphorus concentration of leaves nearly so $(0.05<\mathrm{p}<0.10)$.

At 3 of the 4 other sites growth of Heterozostera tasmanica increased when sediments had been enriched with a mixture of nitrogen and phosphorus although not all changes were significant. At South Sands $H$. tasmanica growing in enriched sediments had twice the density of leaf clusters, $50 \%$ greater leaf dry weight per square meter and plants $20 \%$ taller than seagrasses growing in control plots (Table 2). At West Channel there was a $30 \%$ increase and at Clifton Springs a $50 \%$ increase in all 3 growth parameters due to enrichment by nitrogen and phosphorus. In contrast, at Prince George Bank, none of the growth parameters recorded for $H$. tasmanica increased significantly after enrichment of the sediments with a mixture of nitrogen and phosphorus (Table 2).

\section{DISCUSSION}

The increase in growth resulting from enrichment with nitrogen indicates that Heterozostera tasmanica was nitrogen limited at the Rye site. There is evidence that the seagrass response to enrichment with nitrogen plus phosphorus at three of the other sites was also due

Table 4. Heterozostera tasmanica. Concentration (\% of dry weight) of total nitrogen and total phosphorus in leaves and roots/ rhizomes at the beginning (September 1982) and end (February 1983) of experimental enrichment of the sediments with nitrogen alone or phosphorus alone or a mixture of both nitrogen and phosphorus at the Rye experimental site. Mean $\pm S E, n=3$ plots. The significance of the Fratios are indicated for 2-way ANOVA (nitrogen enrichment $x$ phosphorus enrichment) of the February 1983 data: $\cdot \mathrm{p}<0.05 ; \cdots \mathrm{p}<0.001 ; \mathrm{ns}=$ not significant, $\mathrm{p}>0.05$

\begin{tabular}{|c|c|c|c|c|}
\hline & \multicolumn{2}{|c|}{ Percentage phosphorus in } & \multicolumn{2}{|c|}{ Percentage nitrogen in } \\
\hline & leaves & roots \& rhizomes & leaves & roots \& rhizomes \\
\hline Beginning (Sep 82) & $0.29 \pm 0.01$ & $0.17 \pm 0.01$ & $1.50 \pm 0.03$ & $0.51 \pm 0.02$ \\
\hline \multicolumn{5}{|l|}{ End } \\
\hline Control (Feb 83) & $0.32 \pm 0.01$ & $0.20 \pm 0.01$ & $1.68 \pm 0.04$ & $0.52 \pm 0.04$ \\
\hline$+N($ Feb 83$)$ & $0.29 \pm 0.01$ & $0.15 \pm 0.01$ & $2.08 \pm 0.01$ & $0.87 \pm 0.02$ \\
\hline$+\mathrm{P}($ Feb 83$)$ & $0.40 \pm 0.02$ & $0.22 \pm 0.02$ & $1.67 \pm 0.07$ & $0.51 \pm 0.01$ \\
\hline$+N+P($ Feb 83) & $0.35 \pm 0.03$ & $0.18 \pm 0.02$ & $2.14 \pm 0.08$ & $0.87 \pm 0.07$ \\
\hline \multicolumn{5}{|l|}{ ANOVA } \\
\hline $\mathrm{N}$ enrichment & ns & $\cdot$ & $\cdots$ & $\cdots$ \\
\hline P enrichment & $\cdot$ & ns & ns & ns \\
\hline $\mathrm{N} \times \mathrm{P}$ interaction & ns & ns & ns & ns \\
\hline
\end{tabular}


to the nitrogen addition. Moreover, because the DIN and phosphate concentrations in unenriched sediment interstitial water at the Rye site were similar to the other sites enriched with both nitrogen and phosphorus, it is likely that the increase in growth due to $N+P$ additions was due to the added $N$ only. The finding that nitrogen probably limits $H$. tasmanica growth at 4 of the 5 sites that were tested indicates that nitrogen limitation is widely distributed among the H. tasmanica beds in Port Phillip Bay

At one site (Prince George Bank) Heterozostera tasmanica did not respond to enrichment with a mixture of nitrogen and phosphorus. Because the method of treatment was the same at all 5 sites, similar effects were expected. However, at Prince George Bank the sediments appeared to be more disturbed by water currents or benthic fauna or both (many granules of Osmocote were seen lying on the sediment surface 1 mo after treatment) and at the end of the experiment the concentrations of DIN in the treated plots and the control plots were not significantly different (Table 2). H. tasmanica is sparsely distributed at this site and the substratum probably had been disturbed by stronger water currents than occur at the other sites which have a higher density of seagrasses (Harlin et al. 1982, Fonseca et al. 1983). Therefore, the lack of apparent response to the attempted nutrient enrichment at Prince George Bank is attributed to an ineffective treatment at this site.

The increase in growth of Heterozostera tasmanica to nutrient enrichment was measured as increased density of leaf clusters, leaf dry weight and canopy height. Similarly, density, leaf dry weight, leaf growth and rhizome growth of the seagrass Zostera marina have all increased when plants were experimentally enriched with nutrients (Orth 1977, Harlin \& ThorneMiller 1981, Orth \& Moore 1982).

In contrast in Western Port, where seagrasses grew over $250 \mathrm{~km}^{2}$ in the early 1970s (Bulthuis 1981) but have declined since then (Shepherd et al. 1989), Heterozostera tasmanica did not exhibit increased density or biomass in response to nutrient enrichment (Bulthuis \& Woelkerling 1981). The differences between the responses of $H$. tasmanica in Port Phillip Bay and Western Port may be due to the differences in the nutrient content of the sediment interstitial water. In Western Port concentrations beneath seagrasses range from 200 to $1700 \mu \mathrm{M}$ ammonium and 3 to $60 \mu \mathrm{M}$ reactive phosphate (Bulthuis \& Woelkerling 1981) whereas in Port Phillip Bay concentrations ranged from 11 to $19 \mu \mathrm{M}$ DIN (primarily ammonium) and 6 to $8 \mu \mathrm{M}$ reactive phosphate (present study). In addition to differences in sediment chemistry, the 2 bays also differed substantially in open-water chemistry. Much of the Port Phillip Bay watershed is urbanized and sewage from the city of Melbourne has been discharged into Port Phillip Bay for about 90 yr. Consequently, the mean nutrient concentrations in the water $\left(2.0 \mu \mathrm{M} \mathrm{PO}_{4}\right.$ and 0.7 MM DIN; R. Cowdell, Marine Science Laboratories unpubl.) are about 10 times and 2 times the means of those in Western Port $10.2 \mu \mathrm{MPO}_{4}{ }^{-3}$ and 0.3 MM DIN; Ministry for Conservation 1975) which has a forested and agricultural watershed. On the basis of the experimental results on $H$. tasmanica in these 2 bays of contrasting nutrient concentration in the sediments and in the open water, we suggest that irrespective of elevated open water concentrations of DIN and phosphate and the complex inputs and losses of nutrients in seagrass beds (Hemminga et al. 1991) the nutrient status of the sediments will determine whether or not seagrass growth is nutrient limited.

Moreover, this proposition is consistent with a suggestion by Dennison et al. (1987) that growth of eelgrass is limited when nitrogen concentration in the interstitial water is less than $100 \mu \mathrm{M} \mathrm{NH}_{4}+$ At our sites in Port Phillip Bay, where concentrations of DIN in the interstitial water ranged from 11 to $19 \mathrm{mM}$, growth of Heterostera tasmanica was clearly limited by nitrogen. At sites in Western Port, where concentrations of DIN in the interstitial water ranged from 200 to $1700 \mu \mathrm{M}$, $H$. tasmanica responded very little to enrichment with nitrogen (Bulthuis \& Woelkerling 1981). Since fine grain sediments (clay and mud) generally have a higher capacity to absorb ammonium and phosphate ions than do coarser sediments such as sand, seagrasses growing on muddy sediments, such as those in Western Port (Bulthuis \& Woelkerling 1981), will tend to be nutrient sufficient whereas seagrasses growing on sandy sediments such as that of Port Phillip Bay (present study) or Chesapeake Bay (Orth 1977) will be nutrient deficient.

Our results show that growth of Heterozostera tasmanica in Port Phillip Bay, Australia, generally is limited by nitrogen concentrations in the interstitial water of the sediments during spring and summer. Differences in the nutrient concentrations in the interstitial water of the sediments account for the differences in the positive response of $H$. tasmanica to nutrient enrichment of substrata in Port Phillip Bay compared to the response of $H$. tasmanica in Western Port.

Acknowledgements. Sincere thanks to the staff of Marine Science Laboratories for technical assistance, particularly the skippers (John Barry and Ivor Guest) and the crew of 'Melita' and 'Capitella' for assistance in the field and relocating experimental sites, to Brett Errey for help with sampling sediment interstitial water, Andy Longmore for nutrient analysis, Trevor Theodoropoulis for chlorophyll analysis, Kathy Venters for computing assistance, Murray Smith for compiling the maps on distribution of seagrasses in Port Phillip Bay, Gary Critchley for assistance throughout the study and to Darwin 
Evans and 2 anonymous reviewers for helpful comments on the manuscript. Support from the Victorian Department of Conservation and Environment is gratefully acknowledged but the views expressed in this paper do not necessarily reflect those of the Department.

\section{LITERATURE CITED}

Axelrad, D. M., Poore, G. C. B., Arnott, G. H., Bauld, J., Brown, V., Edwards, R. R. C., Hickman, N. J. (1981). The effects of treated sewage discharge on the biota of Port Phillip Bay, Victoria, Australia. In: Neilson, B. J., Cronin, L. E. (eds.) Estuaries and nutrients. Humana Press, Clifton, p. 279-306

Beasley, A. W (1966). Port Phillip survey 1957-1963. Bottom sediments. Mem. Nat. Mus. Vict. 27: 69-105

Boon, P. I. (1986). Nitrogen pools in seagrass beds of Cymodocea serrulata and Zostera capricorni of Moreton Bay, Australia. Aquat. Bot. 25: 1-19

Borum, J., Murray, L., Kemp, W M. (1989). Aspects of nitrogen acquisition and conservation in eelgrass plants. Aquat. Bot. 35: 289-300

Brix, H., Lyngby, J. E. (1985). Uptake and translocation of phosphorus in eelgrass (Zostera marina). Mar. Biol. 90: 111-116

Bulthuis, D. A. (1981). Distribution and summer standing crop of seagrasses and macro-algae in Western Port, Victoria Proc. R. Soc. Vict. 92:107-112

Bulthuis, D. A. (1982). Distribution of seagrasses in Port Phillip, Victoria. Mar. Sci. Lab. Tech. Rep. No. 5. Victoria (Australia) Ministry for Conservation, Melbourne

Bulthuis, D. A., Woekerling, W. J. (1981). Effects of in situ nitrogen and phosphorus enrichment of the sediments on the seagrass Heterozostera tasmanica (Martens ex Aschers.) den Hartog in Western Port, Victoria, Australia. J. exp. Mar. Biol. Ecol. 53: 193-207

Bulthuis, D. A., Woekerling, W. J. (1983a). Seasonal variation in standing crop, density and leaf growth rate of the seagrass, Heterozostera tasmanica (Martens ex Aschers.) den Hartog in Western Port and Port Phillip Bay, Victoria, Australia. Aquat. Bot. 16: 111-136

Bulthuis, D. A., Woelkerling, W. J. (1983b). Biomass accumulation and shading effects of epiphytes on leaves of the seagrass, Heterozostera tasmanica, in Victoria, Australia. Aquat. Bot. 16: 137-148

Dennison, W. C., Aller, R. C., Alberte, R. (1987). Sediment ammonium availability and eelgrass (Zostera marina) growth. Mar. Biol. 94: 469-477

Fonseca, M. S., Zieman, J. C., Thayer, G. W., Fisher, J. S. (1983). The role of current velocity in structuring eelgrass (Zostera marina L.) meadows. Estuar. coast. Shelf Sci. 17: 367-380

Harlin, M. M., Thorne-Miller, B. (1981). Nutrient enrichment of seagrass beds in a Rhode Island coastal lagoon. Mar. Biol. 65: 221-229

Harlin, M. M., Thorne-Miller, B., Boothroyd, J. C. (1982). Seagrass-sediment dynamics of a flood-tidal delta in Rhode Island (U. S. A.). Aquat. Bot. 14: 127-138

Hemminga, M. A., Harrison, P. G. van Lent, F. (1991). The balance of nutrient losses and gains in seagrass meadows. Mar. Ecol. Prog. Ser. 71: 85-96

lizumi, H., Hattori, A. (1982). Growth and organic production of eelgrass (Zostera marina L.) in temperate waters of the Pacific Coast of Japan. III. The kinetics of nitrogen uptake. Aquat. Bot. 12: 245-256

Jeffrey, S. W., Humphrey, G. F. (1975). New spectrophotometric equations for determining chlorophylls $a, b, c$, and

This article was presented by C. Levings, West Vancouver, British Columbia, Canada $c_{2}$ in higher plants, algae and natural phytoplankton Biochem. Physiol. Pflanz. 167: 191-194

Loder, T C., Lyons, W. B., Murray, S., McGuinness, H. D. (1978). Silicate in anoxic pore waters and oxidation effects during sampling. Nature 273: 373-374

McRoy, C. P., Barsdate. R. J. (1970). Phosphate absorption in eelgrass. Limnol. Oceanogr 15: 6-13

Ministry for Conservation (1975). Westernport Bay environmental study 1973/74. Victoria (Australia) Ministry for Conservation, Melbourne

Orth, R. J. (1977). Effect of nutrient enrichment on growth of the eelgrass Zostera marina in the Chesapeake Bay, Virginia, U.S.A. Mar. Biol. 44: 187-194

Orth, R. J., Moore, K. A. (1982). The effect of fertilizers on transplanted eelgrass, Zostera marina L., in the Chesapeake Bay. In: Stovall, R. (ed.) Proc. 9th annual conf. wetlands restoration and creation. Hillsborough Community College, Tampa, p. 104-131

Perez, M., Romero, J., Duarte, C. M., Sand-Jensen, K. (1991). Phosphorus limitation of Cymodocea nodosa growth. Mar. Biol. 109: 129-133

Powell, G. V. N., Fourqurean, J. W., Kenworthy, W. J., Zieman, J. C. (1989). Experimental evidence for nutrient limitation of seagrass growth in a tropical estuary with restricted circulation. Bull. mar. Sci. 44: 324-340

Pulich, W M. Jr (1985). Seasonal growth dynamics of Ruppia maritima L. s. l. and Halodule wrightii Ashers. in southern Texas and evaluation of sediment fertility status. Aquat. Bot. 23: $53-66$

Roberts, M. H. Jr, Orth, R. J., Moore, K. A. (1984). Growth of Zostera marina L. seedlings under laboratory conditions of nutrient enrichment. Aquat. Bot. 20: 321-328

Shepherd, S. A., McComb, A. J., Bulthuis, D. A., Neverauskas, V., Steffensen, D A., West, R. (1989). Decline of seagrasses. In: Larkum, A. W. D., McComb, A. J., Shepherd, S. A. (eds.) The biology of seagrasses. Elsevier, Amsterdam. p. 346-393

Short, F. T. (1983a). The seagrass, Zostera marina L.: plant morphology and bed structure in relation to sediment ammonium in Izembek Lagoon, Alaska. Aquat. Bot. 16: $149-161$

Short, F. T. (1983b). The response of interstitial ammonium in eelgrass (Zostera marina L.) beds to environmental perturbations. J. exp. mar. Biol. Ecol. 68: 195-208

Short, F. T (1987). Effects of sediment nutrients on seagrasses: literature review and mesocosm experiment. Aquat. Bot. 27: $41-57$

Short, F. T., McRoy, L. P. (1984). Nitrogen uptake by leaves and roots of the seagrass Zostera marina L. Bot. Mar. 27: 547-555

Short, F. T., Dennison, W. C., Capone, D. G. (1990). Phosphoruslimited growth of the tropical seagrass Syringodium filiforme in carbonate sediments. Mar. Ecol. Prog. Ser 62: $169-174$

Strickland, J. D. H., Parsons, T. R. (1972). A practical handbook of seawater analysis, 2nd edn. Bull. Fish. Res. Bd Can. 167: $1-310$

Suchanek, T. H. (1983). Control of seagrass communities and sediment distribution by Callianassa (Crustacea, Thalassinidea) bioturbation. J. mar Res. 41: 281-298

Thursby, G. B., Harlin, M. M. (1982). Leaf-root interaction in the uptake of ammonia by Zostera marina. Mar Biol. 72: 109-112

Zimmerman, R. C., Smith, R. D., Alberte, R. S. (1987). Is growth of eelgrass nitrogen limited? A numerical simulation of the effects of light and nitrogen on the growth dynamics of Zostera marina. Mar. Ecol. Prog. Ser. 41: 167-176

Manuscript first received: April 20, 1992

Revised version accepted: October 8, 1992 